\title{
Cardiac Resident Stem Cells: Work (Still) in Progress
}

\author{
Antonio Paolo Beltrami ${ }^{1,2}$, Daniela Cesselli, ${ }^{1,2,3 *}$ and Carlo Alberto Beltrami ${ }^{1,2,3}$ \\ ${ }^{1}$ Department of Medical and Biological Sciences, University of Udine, 33100 Udine, Italy \\ ${ }^{2}$ Interdepartmental Center for Regenerative Medicine, University of Udine, 33100 Udine, Italy
}

${ }^{3}$ Pathology Department, Azienda Ospedaliero-Universitaria of Udine, 33100 Udine, Italy

\begin{abstract}
Nine years after the existence of resident Cardiac Stem Cells was first demonstrated, and despite the fact that we are right now evaluating the preliminary and promising results of the first phase I clinical trials, our understanding of the mechanisms responsible for cardiac regeneration is still partial and the ability to take advantage of it for therapeutic purposes can be considered still rudimentary. However, the worldwide urgency of developing new regenerative therapeutic strategies to reverse the progression of advanced heart failure is funneling a multidisciplinary effort aimed at better comprehending the biological pathways governing cardiac regeneration.

Therefore, in this paper we are critically reviewing the novel scientific evidences regarding: the multiplicity of stem cell populations hosted in the heart; the mechanisms regulating the cardiac embryonic development, such as the epithelial to mesenchymal transition, that may play a part in pathology too; the instructive micro-environmental factors acting within the Cardiac Stem Cell niche and the information gained from clinical trials. Hopefully the consideration of all these aspects will yield potential new targets and more effective strategies for cardiovascular regenerative therapies.
\end{abstract}

Keywords: Cardiac Resident Stem Cells; CSC Niches; Myocyte; Cardiospheres

\section{Introduction}

\section{Why do we need to continue investigating on Cardiac Stem} Cells?

Cardiac Stem Cells (CSC) can be defined as a population of adult primitive cells endowed with stem cell properties, namely selfrenewal, clonogenicity, multipotency and in vivo regenerative capacity [1]. In fact, when injected into injured myocardium, CSC regenerate functionally competent cardiac tissue, being able to give rise to all the major cardiac cell lineages [2]. This rare population resides in specific anatomic regions of the myocardium, the so-called CSC niches, which are localized mainly in the atria and apex of the heart [3]. Stem cell niches are defined as a specialized microenvironment able to fine tuning primitive cell proliferation and differentiation, thus regulating how stem cells participate in tissue generation, maintenance and repair [4]. Therefore, CSC are considered both to be at the helm of the cardiac turnover and to play a fundamental role in the adaptive response of the myocardium to cardiac injury, either in acute or chronic pathological settings $[5,6]$.

As throughly described, CSC were first isolated from rat hearts 9 years ago by Anversa et al., using, as a marker, the Stem Cell Factor Receptor, c-Kit [2]. Few years later, the same marker resulted to be effective in isolating CSC also from human hearts [7]. Self-renewing, multipotent, clonogenic, cardiac-derived- human stem cells, characterized by in vivo regenerative potential, were also isolated with an alternative method by Messina et al., taking advantage of the ability of these primitive cells to grow as cardiospheres [8]. The therapeutic effectiveness demonstrated by both human CSC and cardiospheres in diverse preclinical models of cardiac damage $[7,9]$, have funneled the beginning of phase I clinical trials whose preliminary and promising results have been recently published $[10,11]$.

However, despite the fact that human CSC appear to follow a seemingly straight bench-to-bedside path, the scientific literature is still characterized by sometimes contradictory experimental evidences, thus indicating that we are still far away from reaching a definitive conclusion on many CSC-related issues. Specifically:

1. There are still doubts on the existence of CSC and of a cardiac turnover in the adult heart. While promising results of two phase I clinical trials that experimented the use of human CSC $[10,11]$ for cardiac cell therapy have been recently published, several authors still continue to manifest their disbelief in the existence of a pool of primitive cells that reside in the heart [12]. The inadequate capacity of the heart to repair itself, due either to the incapacity of cardiac myocytes to proliferate or to the failure to mobilize stem cells, has been utilized as an argument in support to this static view.

2. Multiple CSC populations have been described, both in adult and in developing hearts, generating some confusion. Since the first description of the existence of CSC [2], accumulating data confirmed the persistence, both under physiologic and pathologic conditions, of a post-natal production of cardiac myocytes, together with a continuous myocyte turnover $[3,5,13,14]$. However, since several cell types have been described as being involved in myocyte renewal, results have been interpreted as contradictory, while they are just delineating the complexity of a biological system [15].

3. Paucity of knowledge on mechanisms and micro environmental clues able to direct CSC function. Stem cells can correctly exert their

*Corresponding author: Daniela Cesselli, Pathology Department, Azienda Ospedaliero-Universitaria di Udine Pad.13, Piazzale S.Maria della Misericordia 15, 33100 Udine, Italy, Tel: +39 0432 559400; Fax +39 0432 559420; E-mail: daniela.cesselli@uniud.it

Received May 04, 2012; Accepted June 15, 2012; Published June 17, 2012

Citation: Beltrami AP, Cesselli D, Beltrami CA (2012) Cardiac Resident Stem Cells: Work (Still) in Progress. J Stem Cell Res Ther S9:001. doi:10.4172/21577633.S9-001

Copyright: (c) 2012 Beltrami AP, et al. This is an open-access article distributed under the terms of the Creative Commons Attribution License, which permits unrestricted use, distribution, and reproduction in any medium, provided the original author and source are credited. 
function only when inserted into a specialized microenvironment, able to control and coordinate CSC proliferation and differentiation [4]. Unfortunately, we have just begun to gather information on the mechanisms responsible for these functions [16], whose understanding would definitely improve the efficacy of cell therapies. One example of our limited understanding of such mechanisms is given by our still insufficient capability to regenerate myocardium by employing pluripotent stem cells (i.e. embryonic stem cells and induced Pluripotent Stem cells -iPS-). These latter, although powerful, are limited by several unsolved problems [17], such as immuno-rejection and tumorigenicity. While the first issue may be solved employing iPS, the latter could be circumvented pre-differentiating the cells before their use. Nonetheless, it has not yet been established which is the best strategy to efficiently obtain cardiac commitment [18]. In this regard, an intense research is ongoing to identify embryological and adult pathways of cardiomyocyte specification and differentiation that could be employed to move pluripotent stem cells to the clinical settings. Among them, it would be fundamental to get insights into embryological mechanisms such as the epithelial to mesenchymal transition and to better comprehend the micro environmental pathways acting within the CSC niches.

4. Adult stem cells, other than CSC, are able to regenerate viable myocardium. Advanced chronic heart failure represents a worldwide primary clinical problem [19] and it is considered top priority to offer to patients with advanced disease a therapeutic alternative to heart transplantation. In fact, this latter represents nowadays the only available cure, but, because of scarcity of donated hearts, it is accessible only to a minority of patients. As a consequence, a considerable effort has been made in developing regenerative therapeutic strategies aimed at reverting the progression of advanced heart failure [17,20,21]. However, CSC were considered, for a long time, to be too rare, too difficult to be isolated and expanded in vitro to be of practical use. This long-held consideration induced several scientists to investigate the regenerative capacity of non-cardiac progenitor cells [22]. This approach was funneled by scientific works demonstrating that even adult stem cells possess a certain grade of developmental plasticity that make them, especially if of mesodermal origin, able to differentiate into cardiac cells, if located in the appropriate niche $[23,24]$. With this aim, stem cells of non-cardiac origin were employed experimentally to treat patients affected either by acute or chronic heart diseases. While early phase clinical trials showed very promising results, larger ones demonstrated a modest improvement in cardiac function, thus casting doubts on the magnitude of the beneficial effect that could be obtained by employing this strategy (see below) [17,20,21].

For these reasons, aim of this review is to illustrate the increasingly complex and complete picture that is emerging from stem cell (SC) studies and to present evidences supporting the role played by CSC not only in cardiac cell physiology and pathology, but also in cardiac embryology, in an attempt to reveal all the aspects that must be taken into consideration in defining an effective cardiac regenerative strategy. A perspective on the employment of CSC-therapies in the clinical arena will be given as well.

\section{Myocyte Turnover and Identification of CSC}

It has been a difficult task to establish if we are limited with the cardiomyocytes we are born with or if they can also be generated later in life. Although several authors tried to challenge the view of the heart as a static organ over the years [25], myocyte turnover was accepted only recently. The main milestones in this paradigm shift were: the demonstration of the intense myocyte proliferation that occurs, in human hearts, both acutely post-MI [13] and in cardiac hypertrophy secondary to aortic stenosis [26], and, more recently, the quantification of the cardiomyocyte turnover either through radiocarbon dating [27] or combining morphometric data with mathematical models [5]. Although we are still far away from an unambiguous quantification of the cardiac turnover [5,27], the evidence that cardiac myocytes can be generated postnatally has been accepted.

The next fundamental question that was addressed by the scientific community, over the last 5-10 years, regarded the origin of these renewing myocytes. In the ' 90 s authors believed that a subset of non terminally differentiated myocytes could be retained in adult hearts $[28,29]$, while in the 2000s we assisted to a paradigm shift; authors hypothesized that newly formed myocytes could be generated by stem/progenitor cells $[30,31]$. In order to test this hypothesis, sexmismatched cardiac transplants were studied, and scientists observed that cardiac myocytes, smooth muscle cells and endothelial cells of recipient origin could be identified in implanted hearts [30,31]. In addition, undifferentiated cells, expressing stem cell markers shared by hematopoietic stem cells, such as c-Kit, Sca1, and MDR1, were documented as integrated in the cardiac architecture [30,31]. These results were interpreted as the first clues indicating the existence, within the heart, of cells possessing stem cell features, migratory abilities and the potential to differentiate into myocardial lineages. Whether these cells were of hematopoietic origin or originated from the recipient atria could not be discriminated at that time. More recently, the origin of renewing myocytes was addressed utilizing elegant genetic fate mapping studies. This way, Hsieh et al. showed, in a murine model, that myocyte renewal is sustained by undifferentiated cells only in pathological conditions [14]. A possible explanation for this is that cardiac progenitors expressing $\alpha$ - MHC [32] are responsible for myocyte turnover in physiological conditions, while primitive cells are progressively recruited with increasing tissue damage.

The prospective isolation of CSC was a challenge since, in early 2000s, a distinguishing cardiac resident stem/progenitor cell marker was not available; for this reason, antigens or enzymatic activities expressed by other SC types were initially utilized [15]. Specifically, Hoechst effluxing [33,34], c- $\mathrm{Kit}^{+}[2]$, and Sca- ${ }^{+}$[35] cells, displaying, both in vitro and in vivo, SC features were isolated from adult mammalian hearts and char acterized [36]. An alternative approach was to culture candidate SCs under stringent conditions, able to prevent the expansion of differentiated cell contaminants [8,37]. This way, cardiosphere forming cells and Multipotent Adult Stem Cells (MASCs) were obtained from human hearts $[8,37]$. This strategy was criticized, as the nature of cells dispersed from intact tissue sources could be potentially altered by long-term culture, thus determining tissue culture artifacts [38]. However, in SC biology, as very elegantly summarized by Kirkland, it has to be considered a form of uncertainty principle by which it is very unlikely to simultaneously measure the capability of a cell to proliferate and differentiate [24,39]. Therefore, in order to overcome this problem, researchers used lineage-tracing analysis as an alternative method. This way Isl-1 ${ }^{+}[40,41]$, Flk1 ${ }^{+}$ $[41,42], \mathrm{Wt1}^{+}$[43], Tbx18 ${ }^{+}[44,45]$, Scleraxis $^{+}(\mathrm{Scx})$ and Semaphorin $3 D$ $(S e m a 3 D)^{+}[46]$ multipotent cells were identified. However, these studies did not provide information on the self-renewal, clonogenicity 
and multipotentiality of progenitor cells in vivo. These limitations were recently circumvented utilizing in vivo viral-tagging protocols, that, taking advantage of the semi-random insertion of retroviral and lentiviral vectors into the host genome, allowed the identification of the progeny of differentiating SCs [47], corroborating the hypothesis of the origin of cardiac myocytes from CSC in the adult.

In conclusion, nowadays the collected experimental evidences sufficiently support the notion that adult heart is a self-renewing organ whose turnover is guaranteed by a resident primitive cell pool. Seemingly, prospective isolation experiments, lineage tracing analyses and in vivo viral-tagging protocols failed in identifying, as a CSC, the same identical cell. However, these divergent results can be somehow reconciled taking into consideration the role played by CSC during development and in adulthood.

\section{CSC in Development and Adulthood}

From an historic perspective, the identification in the heart of a population of cells fulfilling all the stem cell criteria (i.e. a population of self-renewing, clonogenic and multipotent cells able to regenerate, in vivo, a damaged organ), was first obtained in adult organisms, while the involvement of primitive cells in cardiac development is a more recent finding.

The first reports on the prospective isolation of putative CSC were performed investigating the "side population" (SP). This latter is a class of highly primitive stem cells that was first described by Goodell et al.in the bone marrow [48]. A cardiac SP (CSP) was initially identified by Hierliy et al. [33]. They demonstrated that SP cells constituted $\approx 1 \%$ of freshly dissociated cardiac cells and could be either differentiated into cells expressing cardiomyocyte markers, when co-cultured with neonatal myocytes, or induced to form hematopoietic colonies, when cultured in a semisolid medium. However, the in vivo regenerative potential of these cells was not assayed.

The first work that identified a cardiac resident SC fulfilling every stem cell feature was carried out a few years later in the rat. For this purpose, putative cardiac resident stem cells were prospectively isolated using c-Kit, which is the receptor for Stem Cell Factor (SCF), as a marker [2]. In the murine myocardium there was about one cell expressing c-Kit, but not expressing hematopoietic markers (Lin'), per $10^{4}$ myocytes [2]. These cells, once isolated from adult rat hearts, displayed, in vitro, self-renewal, clonogenicity, and multipotency, while, in vivo, they could repair infarcted hearts. Specifically, when injected into the border zone of infarcted hearts, $\mathrm{c}-\mathrm{Kit}^{+}$cells contributed to cardiac regeneration, in the absence of cell fusion, generating new capillaries, arterioles and striated muscle cells, thus determining the reappearance of contractions in the infarcted area. Importantly, newly formed myocytes were characterized by the same mechanical properties of fully mature spared myocytes [2]. Additionally, some years later, Anversa et al. proved the functional integration of $\mathrm{c}-\mathrm{Kit}^{+}$ cells in the myocardium and their role in tissue homeostasis [3]. Specifically, they searched for stem cell niches localized in specific areas of the myocardium, demonstrating that these specialized structures were mainly located in atria and apex and contained CSC and lineage committed cells, which were connected to supporting cells, represented by myocytes and fibroblasts [3].

Almost simultaneously to the description of $\mathrm{c}-\mathrm{Kit}^{+} \mathrm{CSC}$, Schneider et al. described a population of cardiac resident progenitor cells expressing the Stem Cell Antigen-1 (Sca1) [35]. These cells, that comprised $14-17 \%$ of the non-myocyte adult cardiac cell population, were negative for: blood cell lineage markers, c-Kit, Flt-1, Flk-1, and VE-Cadherin, while they were in large part positive for CD31 and $\mathrm{CD} 38$. Sca1 ${ }^{+}$cells possessed telomerase activity, expressed the cardiac transcription factors GATA4, ME2C, TEF-1, while they were negative for $\mathrm{Nkx} 2.5$, $\alpha$ - and $\beta$-MHC, atrial and ventricular myosin light chain-2, cardiac and skeletal $\alpha$-actin, and CRP3. When treated with the demethylating agent 5-Azacytidine, $\mathrm{Sca}^{+}$cells differentiated into Nkx2.5+, $\alpha$ - and $\beta$-MHC+, $\alpha$-sarcomeric actin+, and Troponin I+ cardiomyocytes. When tested in a mouse ischemia/reperfusion injury model, $\mathrm{Sca}^{+}$cells showed their ability to differentiate into $\alpha$-sarcomeric actin positive cells in vivo. However, about half of the putative newlyformed myocytes were indeed formed by cell fusion, as shown utilizing the Cre/Lox donor/recipient pair. This paper, although pioneering, did not investigate the vasculogenic potential of Sca1+ cells nor their clonogenic ability [35].

As previously mentioned, the fact that different, and apparently independent, CSC types were isolated from adult murine hearts is not totally unexpected if we consider cardiogenesis.

This latter event occurs through a complex series of events that require the interplay between different cell types [49]. Early studies performed on avians demonstrated the independent formation of cardiac myocytes, fibroblasts, endothelial cells, and smooth muscle cells during heart formation [50]. However, this notion was in part revised studying rodent development [49]. More recently, investigators demonstrated that the heart forms from two separate progenitor cell populations or "heart fields", of which one forms mainly the left ventricle (primary heart field), while the second one (secondary heart field) forms the right ventricle, the outflow tract and the larger part of atria [51,52]. Last, cells migrating from the neural crest [53] and the proepicardial organ [54] take an extremely relevant part to the process of heart formation.

\section{Primary heart field}

Given the complexity of heart development and the seemingly conflicting results, it was relatively recently that researchers started to investigate on the role played by multipotent progenitor cells in heart development. Among the first, Orkin et al. addressed this issue focusing on Nkx2.5 expressing cells [55]. These latter could be identified starting from mouse embryonic day (E) 8.5 and were mostly negative for the transcription factor isl1. In vitro, $\mathrm{Nkx} 2.5^{+}$cells behaved as multipotent progenitors, since they could be differentiated into: smooth muscle cells, functionally competent Purkinje cells, AV node cells, atrial and ventricular myocytes. Importantly, authors utilized an embryonic stem cell (ES) differentiation system to identify, among $>30$ different surface proteins, candidate molecules that could enrich in progenitor cells within Nkx2.5 $5^{+}$cells. They observed that, unlike Sca1 expressing cells, c-Kit was able to select a subpopulation of cells that appeared to be highly proliferative, more undifferentiated, clonogenic and multipotent. Importantly, cells co-expressing c-Kit and Nkx2.5 were documented in vivo, in the developing heart field.

In order to directly visualize and to establish the differentiation potential of $\mathrm{c}-\mathrm{Kit}^{+}$cells in developing mouse embryos, a transgenic mouse expressing the enhanced green fluorescent protein (EGFP) under the control of c-Kit locus was developed [56]. Taking advantage 
of this animal, investigators documented: the presence of c-Kit-EGFP ${ }^{+}$ cells in the atrial and ventricular walls starting from 14.5 days post coitus $(\mathrm{dpc})$, an increase in the total number of these cells as the heart expanded in size, and their decrease in adulthood. c-Kit-EGFP ${ }^{+}$cells, however, could be identified in post-natal hearts too, where they were localized in the atrio-ventricular region, in the atrial and ventricular walls, and in the epicardial border. The majority of c-Kit-EGFP ${ }^{+}$cells isolated from postnatal hearts expressed the primitive intermediate filament nestin, could be expanded in culture, did not co-express Isl1 and could generate endothelial, smooth muscle, and cardiac myocytes at a clonal level in vitro. The same authors took also advantage of this animal model to investigate the involvement of adult c-Kit-EGFP ${ }^{+}$ cells in cardiac repair. Intriguingly, they observed that cardiac damage determines an increased c-Kit-EGFP expression that peaks 7 days postcryoinjury, which occurs in endothelial cells, smooth muscle cells, and mature myocytes of the region bordering the infarcted zone. However, using a similar model, Sussman et al. demonstrated that, after acute myocardial injury, c-Kit ${ }^{+}$cells were involved not only in vascular regeneration, but also in cardiomyogenesis [57]. The role played by c-Kit-positive CSC during development has been recently confirmed by Ferreira-Martins et al. [58]. They showed that the major determinant of cardiac growth, in mice, would be represented by the formation of myocytes from CSC differentiation. In addition, the division of c-Kitpositive CSC was promoted by spontaneous $\mathrm{Ca}(2+)$ spikes. These latter determined the pattern of stem cell replication and the generation of a myocyte progeny at all phases of prenatal life and up to one day after birth [58].

\section{Secondary heart field}

The demonstration that the outflow tract of the heart is not present at the linear heart tube stage dates back to many years ago [59]. Nonetheless, it was necessary to accumulate an important body of work $[40,41,50,60]$ to demonstrate that cells with stem cell properties were implicated in the generation of both the right ventricle and the outflow tract [41]. Specifically, lineage-tracing experiments and studies on mice homozygously null for the transcription factor isl1 demonstrated that isl1-expressing cells would contribute to the majority of cells of: the outflow tract, the right ventricle, and both atria and less than $20 \%$ of cells within left ventricle [40]. Importantly, isl1 seems to be required for crucial developmental steps, such as the proliferation and survival of both pharyngeal endoderm and splanchnic mesoderm, and for the migration of cardiac progenitors into the heart. Although lineage-tracing experiments demonstrated the multipotentiality of isl 1 expressing cells in the embryo, it did not verify if these cells were able to generate fully functional cells, at a clonal level. Two works of Chen et al. addressed this issue $[41,60]$, demonstrating that is $11^{+}$culture-expanded cells, that neither did efflux Hoechst 33342 nor expressed c-Kit, were able to differentiate into fully functional cells. Clonal analysis, utilizing ES derived cells cultured on cardiomyocyte feeder layers, revealed the existence of subsets of double positive cells within a clone: is $11^{+} / \mathrm{flk} 1^{+}$, isl $1^{+} / \mathrm{Nkx} 2.5^{+}$, and flk1 $1^{+} / \mathrm{Nkx} 2.5^{+}$cells. Interestingly, isl $1^{+} / \mathrm{flk} 1^{+} / \mathrm{Nkx} 2.5^{+}$ clones differentiated into all three lineages, while clones generating myocyte-endothelial or smooth muscle-endothelial cells expressed isl1 and flk1, whereas cardiomyocytes and smooth muscle cells were identified both in isl1 ${ }^{+}$and isl1 clones. Therefore, endothelial cells were observed only in isl 1 expressing clones, while Nkx2.5 played a pivotal role in the specification into the myocyte lineage. Importantly, these findings were replicated, even at a clonal level, isolating isll expressing cells directly from mouse embryos. Therefore, is $11^{+}$cells are multipotent cardiovascular progenitors of the secondary heart field, that contribute to the generation of endothelial cells, smooth muscle cells, and cardiomyocytes. However, isl $1^{+}$cells are rapidly lost with development and seem not to be present in adult hearts.

\section{Proepicardial organ}

As outlined above, the contribution of the primary- and the secondary-heart fields to cardiogenesis is complemented by that of the epicardium [38]. In adults, the epicardium, is the visceral layer of the epicardium and is composed of a simple squamous epithelium, similar to other mesothelia. Its major function is to produce the pericardial fluid and to provide a smooth surface on which the heart slides during contraction [61]. However, it is well known that during embryogenesis, proepicardial cells provide the progenitors for the epicardium, coronary smooth muscle, endothelium, and cardiac fibroblasts [62]. The origin of coronary endothelial cells has been disputed for a long time [54,63], although recent data seem to support its emergence from a subset of proepicardial cells [46]. This process that leads to the generation of vasculogenic cells from a mesothelium is a unique in vertebrate development, and has stimulated investigations aimed at verifying if this embryonic property could persist in post-natal hearts. Following this hypothesis, Bader's and de Vries et al. have both demonstrated that adult epicardial cells could maintain part of their embryonic differentiation potential, being able to generate smooth muscle cells $[61,64]$. However, the most compelling evidence of the multipotentiality of epicardial cells comes from recently published papers [43,44,46,65]. Specifically, Zhou et al. identified a novel cardiogenic precursor characterized by the expression of $\mathrm{Wt} 1$, a transcription factor whose expression, during development, is restricted to the proepicardium and epicardium [43]. Lineage-tracing experiments demonstrated that most Wt1-derived cells adopted a smooth muscle cell fate, while a minority of $\mathrm{Wt}^{+}{ }^{+}$cells differentiated into endothelial cells. Importantly, in fetal hearts, $7-10 \%$ ventricular- and $18 \%$ atrial-cardiomyocytes resulted to be derived from $\mathrm{Wt}^{+}$cells [43]. Cai et al., on the other hand, reported the existence, in the pro-epicardium, of a cardiac progenitor cell population expressing the transcription factor Tbx18. This population resulted to contribute to all the major cardiac cell types, myocytes included, in the ventricular septum and in the atrial and ventricular walls [44]. Importantly, Tbx $18^{+}$precursor cells seemed not to originate endothelial cells; these latter could be originated from an independent proepicardial population [46]. In fact, Katz et al. demonstrated that the proepicardium is composed by sub-compartments identified by the markers Scleraxis $(S c x)$ and Semaphorin3D (Sema3D) on one hand, and $T b \times 18$ and $W T 1$ on the other hand. Differently from this latter, the first compartment gives rise mainly to endothelial cells and, at minor extent, to other cardiac fates [46].

Particular interest has been recently arisen by the demonstration of the persistence, during the adulthood of the proepicardial progenitor population marked by the expression of the $\mathrm{Wt} 1$ and Tbx18 proteins, which seems to play a role in response to myocardial injury (see below) $[66,67]$.

Altogether, genetic fate mapping studies show that embryonic cardiogenesis proceeds according to a hierarchical model in which lineage-restricted progenitor cells give rise to the multiplicity of cells present in the adult heart [17]. The variety of CSC isolated from adult heart can reflect the fact that multiple embryological sources contribute 
to the development of this organ and can persist throughout adulthood. Importantly, biological mechanisms, essential during embryogenesis, such as the epithelial to mesenchymal transition, can continue to play a crucial role during adulthood.

\section{Mechanisms able to Direct hCSC Function: Epithelial to Mesenchymal Transition in Development and Adulthood}

Both epithelial mesenchymal transition (EMT) and its reverse process (mesenchymal to epithelial transition -MET-) are aspects of plastic cell behavior that play a crucial role in development [68]. These processes describe the transition from an immobile epithelial cell, bound by adherens junctions to adjacent cells, to a mobile, fibroblastlike mesenchymal cell that loses its cell-cell contacts, in EMT, whereas the reverse occurs during MET [68]. Cells undergoing EMT are characterized by the acquisition of migratory and invasive qualities, stem cell features, prevention of senescence and immunosuppressive properties [69]. Additionally, accumulating evidences indicate a relevant role for these phenomena in pathology.

Three successive cycles of EMT and MET characterize cardiac development [69]. Cardiac mesoderm is first specified during the EMT that occurs at gastrulation, while cardiac progenitors in the splanchnopleura become organized in a two layered epithelium via MET. A secondary EMT occurs when the two cardiogenic areas fold around the primitive foregut. Mesenchymal cells formed during this process undergo a subsequent MET, forming an endocardial tube surrounded by a myocardial epithelium. Finally, endothelial cells from the atrio-ventricular canal undergo a tertiary EMT, forming the endocardial cushion, a structure that gives rise to the atrio-ventricular valvulo-septal complex. Last but not least, epicardial cells undergo EMT to give rise to the endothelial and smooth muscle cells of the coronary vasculature, perivascular, intermyocardial and subendocardial fibroblasts, and even a small number of endocardial cells and myocytes $[43,44,70]$.

Regarding the contribution of EMT in pathology, both its importance in tissue regeneration and in fibrosis have been described.

Adult zebrafish can regenerate a cardiac damage, when up to $20 \%$ of its ventricle is surgically removed [71]. Recent works investigating on the mechanisms responsible for this phenomenon demonstrated that new cardiomyocytes originate from undifferentiated progenitor cells. Additionally, authors showed that myocardial injury activates the entire epicardial cell layer, which expresses developmental markers (Tbx18 and Raldh2), rapidly expands and undergoes an EMT invading the wound, thus providing new vasculature to regenerating muscle [72]. Interestingly, zebrafish display an indefinite growth throughout adulthood. Lowering fish density in the aquarium triggers rapid animal growth and robust cardiomyocyte proliferation throughout the adult ventricle, greater than that observed during slow animal growth or size maintenance [73]. In this experimental setting, it was demonstrated the generation of new myocytes from undifferentiated progenitors and the contribution of pericardial activation, growth and differentiation to the formation of new vessels and epicardial derived cells. In this regard, Limana [74] and coworkers recently demonstrated both that myocardial infarction (MI) induces the up-regulation of WT1, Tbx18, and RALDH2 in epicardial cells and that these cells co-express c-Kit. Last, the injection of pericardial fluid from MI patients induces epicardial cell proliferation and WT1 expression.
As previously mentioned, epicardial $\mathrm{Wt}^{+}$and $\mathrm{Tbx} 18^{+}$cells seem to persist during the adulthood and, in response to myocardial injury, they proliferate and acquire a mesenchymal phenotype. Importantly, these epicardium-derived cells (EPDCs), could act by secreting trophic growth factors into the underlying myocardium [66,67]. Importantly, this cell population can be activated by paracrine factors such as thymosin $\beta 4$ [75]. Cre-LoxP-mediated genetic lineage trace has confirmed that activation of epicardial cells, both during heart development and postnatal heart repair and regeneration, is mediated by an epithelial-to-mesenchymal transition (EMT) [76]. Even more importantly, the Montagnani et al. [65,77] showed not only the presence, in the subepicardium, of a population of c-Kit ${ }^{+}$cells [77], but they documented, at least in vitro, the possibility that $\mathrm{c}-\mathrm{Kit}^{+} \mathrm{CSC}$ could originate from EMT of the epicardial cells [65].

In addition to the role played by EMT in tissue regeneration, recent evidence point to the role played by this mechanism in organ fibrosis [78]. Although tissue fibrosis has been classically considered to be the resultant of the activation and proliferation of resident fibroblasts, recent studies indicate that both bone marrow-derived fibroblast and epithelial cells may contribute, through an EMT, to fibroblast accumulation [78]. Thus, it has been demonstrated the role of EMT in lung-, liver-, kidney-, skin-, and cardiac-fibrosis [78,79]. In this latter case, an endothelial to mesenchymal transition has been described, where TGF- $\beta 1$ signaling seems to be the responsible mechanism for this phenomenon while BMP-7 was able to counteract it.

Altogether these results indicate that cardiac resident cells are endowed with a differentiation plasticity whose mechanism can be partly explained by EMT.

\section{CSC Niches: Looking for Microenvironmental Cues}

Advances in stem cell biology greatly improved our understanding of SC self-renewal and differentiation. Embryonic stem cells, iPS and multipotent adult SCs can be differentiated into several cell types, including cardiac myocytes. Nonetheless, in vivo studies and clinical trials revealed major limitations in reconstituting the myocardium in failing hearts. These limitations include precise control of SC proliferation, survival and phenotype both prior and subsequent to transplantation and avoidance of serious adverse effects such as tumorigenesis and arrhythmias [80]. These crucial functions are played by stem cell niches, specialized tissue domains that regulate adult stem cell quiescence, self-renewal, expansion and differentiation [81].

These structures are characterized by a specialized microenvironment constituted by cells that support stem cell function (supporting cells), specific growth factor gradients and extracellular matrix (ECM) components [81]. In most stem cell systems, stem cell niches have been identified "retrospectively" as sites of stem cell accumulations.

Utilizing this approach, Urbanek et al. identified CSC niches in the mouse as protected areas of the myocardium, mainly localized in the atria and apex [3]. Cardiac myocytes and fibroblasts act as supporting cells in this system, while fibronectin and the $\alpha_{2}$ chain of laminin are part of the specialized extracellular matrix composing CSC niches. Castaldo et al. obtained similar data in human hearts [77], however they also demonstrated that CSC accumulate in the epicardial-subepicardial region of human hearts. Additionally, they demonstrated that laminin1 and $\alpha_{6}$ integrin positive CSC accumulates in these regions. The interaction between this ECM component and its receptor regulates CSC proliferation, apoptosis, and migration [77]. 
CSC is mechanically and electrically coupled with supporting cells through adherens and gap junctions [3]. This feature suggests a potential role for: small molecules (such as miRNAs) [82] and electrolytes, able to cross gap junctions, and membrane bound molecules, presented by supporting cells, in controlling SC fate. In line with this, it has been shown that CSC in the niches expresses Notch1 receptor, while the supporting cells present the Notch ligand Jagged1 [83]. Following this interaction, the Notch1 intracellular domain (N1ICD) is translocated to the nucleus, where it up-regulates $\mathrm{Nkx} 2.5$, thus promoting the formation of cycling myocytes in vitro; additionally, Notch 1 activation downregulates vascular cell specific transcription factors, interfering with endothelial cell and smooth muscle cell differentiation. Last, it has been demonstrated the effect of IP3-induced calcium oscillations in regulating CSC proliferation [58,84]. Although this effect is not mediated by calcium influx through gap junctions, it demonstrates the importance of calcium homeostasis in regulating CSC fate. Additionally it has been speculated that the intercellular passage of calcium may activate in lineage committed cardiac progenitors the release of calcium from the ER conditioning the acquisition of the adult cardiomyocyte phenotype and contractile function.

More recently, in the attempt to apply micro- and nanoscale techniques to recreate SC niches, we gained further insight into key factors responsible, within the niche, for the maintenance and regulation of SC behavior $[80,85]$. Specifically, it has becoming clear that microand nanoscale manipulation of several micro-environmental features, such as scaffold composition, mechanical properties, and threedimensional architecture, can direct SC fate $[80,85]$. This pioneering field has clearly shown the limitations of the conventional biological approaches and will represent a novel tool for developing the next generation of "transplantable SC niches" for regeneration of heart and other tissues $[80,85]$.

In summary, CSC are nested in specialized areas of the myocardium that regulate their state; however, the molecular determinants responsible for this are just starting to be decrypted. This discovery is of paramount importance since it demonstrates that the heart may exert an instructive role on primitive cells [86-88], regulating the fate of plastic cells [89] that may reach the heart even from remote sites, such as the bone marrow. Nanotechnologies, allowing the micro- and nanoscale control of key factors such as scaffold composition, architecture and mechanical forces, would represent a promising tool.

\section{Clinical Trials Using Cardiac-derived Stem Cells}

Although an increasing body of literature has shown, over the last almost ten years, that the use of Cardiac-derived Stem and Progenitor cells attenuates Left Ventricular (LV) remodeling and improves LV function in animal models of both acute and chronic myocardial infarction $[2,7,9,90,91]$, the experimentation of the use of these cells in clinical settings has been carried out only recently. Specifically, three independent groups have started, between the years 2009 and 2010, three distinct Phase I clinical trials (ALCADIA -ClinicalTrials.gov Identifier: NCT00981006-, SCIPIO-ClinicalTrials. govIdentifier:NCT00474461-, and CADUCEUS -clinicaltrials.gov Identifier:NCT00893360-) to investigate feasibility, safety and to have some hints on the efficacy of Cardiac-derived Stem and Progenitor cell treatment of both acute and chronic ischemic heart disease. In two cases (SCIPIO and CADUCEUS), respectively initial results and more definitive ones were recently published $[10,11]$.
SCIPIO trial [10] is a randomized, open-label, single centre trial designed to test the feasibility and safety of a procedure that consists in the collection, expansion in vitro and intracoronary infusion of autologous-, atrial derived- $\mathrm{c}-\mathrm{Kit}^{+} \mathrm{CSC}$. The target population consisted of patients who underwent coronary artery bypass grafting (CABG), and had LV ejection fraction (EF) of less or equal to $40 \%$ and a previous myocardial infarction. Atrial tissue was collected at the time of CABG, processed to obtain growing cultures that were eventually enriched in c-Kit + cells through immunomagnetic separation. Not more than $10^{6}$ cells per patient were injected. In treated patients, on top of clinical assessment and laboratory tests, two-dimensional (2D) and threedimensional (3D) trans-thoracic echocardiograms were done before CSC infusion and at 1 month, 4 months, and 12 months thereafter. In patients without contra indications, cardiac MRI (cMRI) was performed as well. Between March 2009 and April 2011, authors screened 1,385 patients undergoing surgical re-vascularisation. Of these, 1,200 did not meet the inclusion criteria ( $\mathrm{EF}$ was $>40 \%$ ). Of the remainder, 104 were excluded because they either did not meet additional inclusion criteria (e.g. myocardial infarction of $<7$ days, advanced age, poor glycemic control, presence of co-morbidities) or did not will to participate. Therefore, 81 patients were enrolled in two stages: in the first phase (stage A) 25 patients were consecutively enrolled (19 of which were CSC treated and 6 served as controls), while in the second phase (stage B) 56 patients were randomly assigned to either treatment (24 patients) or control (32 patients) groups. At present, 4 months follow-up data are available for 9 CSC treated patients and 4 controls enrolled at stage A and 7 CSC treated patients and 3 controls enrolled at stage B. Results obtained so far indicate that: cells may be produced from almost every patient ( $80 / 81$ patients), $\approx 88 \%$ of the expanded cells are c-Kit ${ }^{+}$, possess long telomeres and $\approx 97 \%$ of these CSC are negative for the senescence marker p16 ${ }^{\mathrm{INK} 4 \mathrm{~A}}$. Functionally, LV Ejection Fraction (LVEF), as assessed by $3 \mathrm{D}$ echocardiography, increased significantly at 1 and 4 months post CSC infusion. In controls, LVEF did not change over the same period. The increase in LVEF in the CSC-treated patients was coupled with a significant improvement in the regional wall motion score index. This was not observed in control patients. cMRI data (available for 7 patients) supported echocardiographic data, showing a significant reduction in infarct size and a significant increase in wall thickening. Altogether these results demonstrate that CSC treatment is feasible, safe (no adverse effects attributable to CSC were noted), and suggests that it may be associated with a reduction in infarct size and a functional improvement in LV systolic function. However, some caveats should be considered: these results are still preliminary and the study (which is a Phase I clinical trial, not a strictly double-blind, fully randomized, placebo-controlled Phase II-III trial) was not designed to test efficacy [10].

CADUCEUS is a randomized open-label trial designed to test the feasibility and safety of a procedure that consists in: the generation of Cardio spheres from endomyocardial biopsies, the in vitro expansion of Cardio sphere Derived Cells (CDC) and their infusion in the infarct-related artery [11]. Quality control of cells was performed by investigating if: more than $95 \%$ of cells expressed CD105, and fewer than $5 \%$ expressed CD45. Karyotype was performed as well to verify euploidy. Investigators enrolled patients who had an acute myocardial infarction in the past 2-4 weeks and a LVEF of $25-45 \%$. A first cohort of patients received a "low cell dose" $\left(12.5 \times 10^{6}\right.$ cells; $\left.n=4\right)$ or standard of care. Once defined as safe by the National Heart, Lung, and Blood Institute (NHLBI) Gene and Cell Therapy Data and Safety Monitoring 
Board (DSMB), a second cohort of patients received a high dose $\left(25 \times 10^{6}\right.$ cells; $\mathrm{n}=12)$. Efficacy of the treatment was evaluated clinically, and by cMRI, performed at baseline, at 6 months for the primary endpoint, and at 12 months to assess longevity of the treatment effects. Between May 2009 and December 2010, 436 patients were screened. Of these, 405 were excluded because they did not meet inclusion criteria. The remainder 31 were randomly allocated to receive either $\mathrm{CDC}(\mathrm{n}=23)$ or standard of care $(n=8) .6$ patients in the CDC arm were excluded because either the procedure did not generate CDC meeting the quality criteria $(n=4)$ or patients withdrew consent or the infarct related artery occluded. Six patients in the CDC group had serious adverse events (one acute myocardial infarction, two cases of chest pain, one coronary re-vascularization, one implantable defibrillator insertion for prophylactic indications, and two other non-cardiac events), while one patient in the control group had atypical chest pain. The serious adverse events were regarded (with the exception of the development of a non-Q wave myocardial infarction in one patient who had received 25 million CDCs 7 months previously) as unrelated or unlikely to be related to the study treatment. As regards efficacy of the treatment, scar size was significantly reduced in CDC treated patients, while remained unchanged in controls. Scar mass too was reduced in CDC treated patients but remained unchanged in controls. By contrast, viable myocardial mass increased in patients who received CDC, while it did not change in controls. Since cMRI observed differences in myocardial mass and scar size could be secondary to the distortion of myocardial architecture by CDC, an experimental animal model mimicking the key features of CADUCEUS was performed (syngeneic CDC given after a myocardial infarction through the intracoronary route in rats) and histological examination of infarcted animal hearts confirmed cMRI data. As regards cardiac function, Investigators did not observe an increase in LVEF, but demonstrated that both contractility and systolic wall thickening were significantly increased by CDC treatment. As a whole, this proof-of-concept clinical study demonstrates that endomyocardial biopsy samples can be used to harvest heart tissue in a minimally invasive manner for treatment. In addition, CDC treatment is feasible, safe, and seems to reduce scar tissue, and increase myocardial mass. However, this trial too was not designed to test efficacy, but rather feasibility and safety.

Last, as regards ALCADIA trial, this study, which has started to recruit patients on April 2010 and is still recruiting participants, is designed to evaluate the safety of the intra-myocardial injection of autologous human Cardiac-derived Stem Cells in association with a gelatin hydrogel sheet incorporating $200 \mu \mathrm{g}$ bFGF. Preclinical data have been obtained in a porcine model [91]. Target population will be heart failure patients with chronic ischemic cardiomyopathy and severe ventricular dysfunction (15\% LVEF 35\%).

\section{Non Cardiac Resident Stem Cells in Cardiac Regeneration Treatment}

As previously mentioned, clinical trials based on the use of stem cells of non cardiac origin started some years before those relying on the injection of CSC [22]. Specifically, skeletal myoblasts, bone marrow mononuclear cells (either unselected, $\mathrm{CD} 133^{+}$or $\mathrm{CD} 34^{+}$cells), circulating progenitor cells, bone marrow-derived and adipose tissuederived mesenchymal stem cells were employed in early phase clinical trials (excellently reviewed in $[17,20,21]$ ). These latter showed, with few exceptions [92], safety, feasibility and suggested a high degree of efficacy.
Table 1 summarizes arguments favoring or against the use of each of these cell types. For some aspects, the use of non-CSC may be advantageous over CSC. Specifically, non-CSC (e.g. bone marrowor peripheral blood-derived SC) are easily accessible and require procedures that could be considered as minimally invasive for the patient and, therefore, repeatable, theoretically, over time. Second, most hematopoietic stem cells (and their subpopulations) could be collected, enriched, and injected after a minimal cell manipulation that does not require in vitro cell expansion, thus greatly simplifying the procedures. However, as regards efficacy, the largest placebocontrolled, randomized, phase II-III clinical trials (especially those experimenting bone marrow mononuclear cells) showed conflicting results $[17,20]$ that were interpreted as the inability of non-CSC to directly take part to the newly formed, functionally competent myocardium. In line with this, several investigators still debate on the in vivo transdifferentiation ability of non-cardiac stem cells and preclinical data, either supporting or neglecting this possibility have been accumulated [93-95]. To reconcile these seemingly contrasting results, investigators have demonstrated that cell-based therapies can exert their positive effects without a direct integration of donated cells into the host tissue, but rather through a powerful paracrine mechanism [96], which may involve exosomes [97]. However a large number of studies is still ongoing and a definitive conclusion on the efficacy of non-CSC-based therapy cannot be drawn yet $[17,20,21]$.

Although not yet ready for clinical trials, great hopes are now placed on induced Pluripotent Stem Cells (iPS). These latter closely resemble embryonic stem cells and were first obtained by Takahashi and Yamanaka by reprogramming in-vitro differentiated cells, such as skin fibroblasts [98]. Specifically, iPS can be derived from individual patients, greatly expanded in vitro and differentiated into cardiac cells, allowing autologous cell transplantation, with a theoretical reduction in risk of immune rejection $[99,100]$. However, this promising strategy is affected by several unsolved problems [17]. For example, since undifferentiated iPS are tumorigenic, they must be pre-differentiated before implantation, although it has not yet been established which is the best strategy to efficiently obtain cardiac commitment [18]. In addition, it has been shown that iPS' residual epigenetic and transcriptional memories of the cell of origin cause a biased differentiation propensity, thus requiring the development of strategies aimed at erasing cellular memory of the somatic cell of origin, thus unleashing the full differentiation capacity of bioengineered iPS [101]. Intriguingly, strategies that may take advantage of this epigenetic memory may be envisioned as well, as elegantly demonstrated by Rizzi et al. who showed that mouse neonatal cardiac myocytes can be efficiently reprogrammed and re-differentiated toward the cardiomyocyte lineage more efficiently then either cardiac fibroblastderived iPS cells or mouse Embryonic Stem cells [102].

Last, two recent examples of direct reprogramming of somatic cells to cardiomyocytes have demonstrated that the fate of stromal cells may be altered in vivo, suggesting that in the future it may be possible to convert scarred tissue to functioning myocardium $[103,104]$.

\section{Conclusions}

Cardiac-resident Stem Cells were first described almost ten years ago. Since that pioneering work, independent investigators have demonstrated that several classes of cells possessing stem cell properties take part to the complex process of cardiac organogenesis 
Citation: Beltrami AP, Cesselli D, Beltrami CA (2012) Cardiac Resident Stem Cells: Work (Still) in Progress. J Stem Cell Res Ther S9:001. doi:10.4172/2157-7633.S9-001

Page 8 of 12

\begin{tabular}{|c|c|c|c|}
\hline Regenerative Strategy & Pro & Contra & Reference [20] \\
\hline $\begin{array}{l}\text { Unselected bone } \\
\text { marrow-derived } \\
\text { cells }\end{array}$ & $\begin{array}{l}\text { 1.largest amount of available data, } \\
\text { 2. minimal cell manipulation with no } \\
\text { requirement for in vitro cell expansion, } \\
\text { 3.presence of a mixed population } \\
\text { containing hematopoietic stem } \\
\text { cells, endothelial progenitors and } \\
\text { mesenchymal stem cells, } \\
\text { 4.safety, } \\
\text { 5.some efficacy. }\end{array}$ & $\begin{array}{l}\text { 1.poorly characterized cell population, } \\
\text { 2.variable results in clinical trials. }\end{array}$ & $\begin{array}{l}\text { Completed Trials: Astami [133], Boost } \\
\text { [132], Cao et al. [131], Fincell [130], } \\
\text { Hebe [129], Janssens et al. [128], } \\
\text { MYSTAR [127], Ramshorst et al. } \\
\text { [126], BELAMI [125], REPAIR-AMI } \\
\text { [124], TOPCARE-CHD [118] and } \\
\text { others. }\end{array}$ \\
\hline $\begin{array}{l}\text { CD133+ bone marrow } \\
\text { cells }\end{array}$ & $\begin{array}{l}\text { 1. minimal cell manipulation with no } \\
\text { requirement for in vitro cell expansion, } \\
\text { 2.use of a better characterized cell } \\
\text { population. }\end{array}$ & $\begin{array}{l}\text { 1. may increase the rate of restenosis, } \\
\text { 2.early phase clinical trials showed benefits, while larger } \\
\text { ones did not. }\end{array}$ & $\begin{array}{l}\text { Completed Trials: Bartunek et al. [123], } \\
\text { Adler et al. [122], CARDIO133 [121]. }\end{array}$ \\
\hline $\begin{array}{l}\mathrm{CD}^{3} 4^{+} \mathrm{CXCR} 4^{+} \text {bone } \\
\text { marrow cells }\end{array}$ & $\begin{array}{l}\text { 1. minimal cell manipulation with no } \\
\text { requirement for in vitro cell expansion, } \\
\text { 2.use of a better characterized cell } \\
\text { population, } \\
\text { 3.patients with Ejection Fraction at } \\
\text { baseline below median benefit the most. }\end{array}$ & $\begin{array}{l}\text { 1.selected cells showed a worse efficacy with respect to } \\
\text { unselected bone marrow cells. }\end{array}$ & Completed Trial: REGENT [120]. \\
\hline $\begin{array}{l}\text { Circulating Progenitor } \\
\text { Cells }\end{array}$ & $\begin{array}{l}\text { 1.improvement in symptoms and exercise } \\
\text { tolerance when given intramyocardially. }\end{array}$ & $\begin{array}{l}\text { 1.necessity for growth factor-induced progenitor cell } \\
\text { mobilization or progenitor cell in vitro culture, } \\
\text { 2.mobilization procedures are associated with } \\
\text { aggravation of restenosis and cardiac enzyme } \\
\text { elevation, } \\
\text { 3.little or no effects when given via intracoronary route. }\end{array}$ & $\begin{array}{l}\text { Completed Trials: ACT34-CMI [119], } \\
\text { TOPCARE-CHD [118], Magic cell } \\
\text { [117]. }\end{array}$ \\
\hline $\begin{array}{l}\text { Mesenchymal stem } \\
\text { cells }\end{array}$ & $\begin{array}{l}\text { 1.feasibility and safety, } \\
\text { 2.possible efficacy. }\end{array}$ & $\begin{array}{l}\text { 1.requirement for more than minimal in vitro cell } \\
\text { manipulation, } \\
\text { 2.less data available, } \\
\text { 3.small number of trials have been completed. }\end{array}$ & $\begin{array}{l}\text { Completed Trials: Prochymal [116], } \\
\text { POSEIDON pilot study (Clinicaltrials. } \\
\text { gov identifier NCT01087996), } \\
\text { C-CURE [115]. }\end{array}$ \\
\hline Cardiac Stem Cells & $\begin{array}{l}\text { 1.employment of a population of cells } \\
\text { isolated from myocardial tissue, } \\
\text { 2.feasibility and safety, } \\
\text { 3.possible efficacy. }\end{array}$ & $\begin{array}{l}\text { 1.requirement for more than minimal in vitro cell } \\
\text { manipulation, } \\
\text { 2.less data available, } \\
\text { 3.only } 2 \text { trials have been completed. }\end{array}$ & $\begin{array}{l}\text { Completed Trials: SCIPIO [10], } \\
\text { CADUCEUS [11]. }\end{array}$ \\
\hline Skeletal myoblasts & $\begin{array}{l}\text { 1.feasibility, } \\
\text { 2.not significant trends towards } \\
\text { improvement. }\end{array}$ & $\begin{array}{l}\text { 1.requirement for more than minimal in vitro cell } \\
\text { manipulation, } \\
\text { 2. ventricular tachicardia. }\end{array}$ & $\begin{array}{l}\text { Completed trials: MAGIC [93], } \\
\text { MARVEL [114]. }\end{array}$ \\
\hline
\end{tabular}

Table 1: Comparison of the major completed clinical trials.

and that, some of them, are retained throughout adulthood, possibly contributing to adult cardiac cell turnover, both in physiologic and pathologic settings.

In order to experiment feasibility, safety, and to have some hints on the efficacy of cell therapy approaches based on the use of Cardiac-resident Stem Cells, three independent laboratories have decided to perform phase I clinical trials. Patients were carefully selected, taking advantage of the experience accumulated with clinical trials experimenting the use of bone marrow cells to treat infracted patients, where those patients that had the greatest benefits were the ones that had the worst cardiac function at the beginning [105]. Results are encouraging and showed feasibility and safety. SCIPIO trial demonstrated also a remarkable improvement in LVEF in treated patients, while CADUCEUS demonstrated a reduction in scar mass and a parallel increase in viable myocardium. Authors consider their results as a challenge to the conventional wisdom that considers cardiac scarring as permanent and that neglects the possibility to restore heart muscle.

These exciting results deserve the investigation of Cardiac-derived Stem Cell therapy in Phase II-III clinical trials to confirm their efficacy, even in trials specifically and rigorously designed to assess this parameter, and to have some hints on their possible superiority with respect to non-CSC.

Although the mechanisms possibly responsible for the positive results obtained with CSC in the clinical arena cannot be asserted, both a direct repair and a paracrine effect have been considered among the most plausible ones [11,90]. Intriguingly, a recent report that compared directly CSC versus non-CSC for their: paracrine effects, tissue engraftment-, differentiation- and anti-apoptotic-capabilities have revealed that the first ones were superior in all these aspects [106].

Finally, we and others have demonstrated that CSC obtained from failing hearts are characterized by cellular senescence processes and functional impairment [107-109], thus suggesting that effectiveness of autologous CSC transplantation could be further improved if we are able to understand and reverse the mechanisms that, in chronic heart failure, impairs the resident CSC reservoir [110-112]. Moreover, regenerative treatments that rely on paracrine mechanisms could be less effective in very sick patients, due to the dysfunction of resident CSC. In this case, other therapeutic options that could modify CSC potency locally may be taken into consideration as well [113]. 
In conclusion, a hard basic-science work is still needed since many questions, such as: how to optimize cell expansion, how to increase cell engraftment (possibly by gaining insights into stem cell niches) or how to empower cell efficacy (by understanding the role played by cell senescence in stem cell dysfunction and organism aging), are still waiting for their responses.

\section{Acknowledgments}

This work is supported by Ministry of Health: GR2007-683407.

\section{References}

1. Smith AG (2006) A glossary for stem cell biology. Nature 441 (4954), 1060.

2. Beltrami AP, Barlucchi L, Torella D, Baker M, Limana F, et al. (2003) Adult cardiac stem cells are multipotent and support myocardial regeneration. Cell 114: 763-776.

3. Urbanek K, Cesselli D, Rota M, Nascimbene A, De Angelis A, et al. (2006) Stem cell niches in the adult mouse heart. Proc Natl Acad Sci USA 103: 92269231.

4. Scadden DT (2006) The stem-cell niche as an entity of action. Nature 441 1075-1079.

5. Kajstura J, Gurusamy N, Ogorek B, Goichberg P, Clavo-Rondon C, et al (2010) Myocyte turnover in the aging human heart. Circ Res 10: 1374-1386.

6. Kajstura J, Urbanek K, Rota M, Bearzi C, Hosoda T, et al. (2008) Cardiac stem cells and myocardial disease. J Mol Cell Cardiol 45: 505-513.

7. Bearzi C, Rota M, Hosoda T, Tillmanns J, Nascimbene A, et al. (2007) Human cardiac stem cells. Proc Natl Acad Sci USA 104: 14068-14073.

8. Messina E, De Angelis L, Frati G, Morrone S, Chimenti S, et al. (2004) Isolation and expansion of adult cardiac stem cells from human and murine heart. Circ Res 95: 911-921.

9. Smith RR, Barile L, Cho HC, Leppo MK, Hare JM, et al. (2007) Regenerative potential of cardiosphere-derived cells expanded from percutaneous endomyocardial biopsy specimens. Circulation 115: 896-908.

10. Bolli R, Chugh AR, D'Amario D, Loughran JH, Stoddard MF, et al. (2011) Cardiac stem cells in patients with ischaemic cardiomyopathy (SCIPIO): initial results of a randomised phase 1 trial. Lancet 378: 1847-1857.

11. Makkar RR, Smith RR, Cheng K, Malliaras K, Thomson LE, et al. (2012) Intracoronary cardiosphere-derived cells for heart regeneration after myocardial infarction (CADUCEUS): a prospective, randomised phase 1 trial. Lancet 379 : 895-904.

12. Parmacek MS, Epstein JA (2009) Cardiomyocyte renewal. N Engl J Med 361 86-88.

13. Beltrami AP, Urbanek K, Kajstura J, Yan SM, Finato N, et al. (2001) Evidence that human cardiac myocytes divide after myocardial infarction. N Engl J Med 344: $1750-1757$

14. Hsieh PC, Segers VF, Davis ME, MacGillivray C, Gannon J, et al. (2007) Evidence from a genetic fate-mapping study that stem cells refresh adult mammalian cardiomyocytes after injury. Nat Med 13: 970-974.

15. Beltrami AP, Cesselli D, Beltrami CA (2011) Multiple Sources for Cardiac Stem Cells and Their Cardiogenic Potential Regenerating the Heart. In Cohen IS Gaudette GR (Eds.), Regenerating the Heart (pp. 149-171): Humana Press.

16. Hosoda T, Zheng H, Cabral-da-Silva M, Sanada F, Ide-Iwata N, et al (2011) Human Cardiac Stem Cell Differentiation Is Regulated by a Mircrine Mechanism. Circulation 123: 1287-1296.

17. Ptaszek LM, Mansour M, Ruskin JN, Chien KR (2012) Towards regenerative therapy for cardiac disease. Lancet 37: 933-942.

18. Cao N, Liu Z, Chen Z, Wang J, Chen T, et al. (2012) Ascorbic acid enhances the cardiac differentiation of induced pluripotent stem cells through promoting the proliferation of cardiac progenitor cells. Cell Res 22: 219-236.

19. Bui AL, Horwich TB, Fonarow GC (2011) Epidemiology and risk profile of heart failure. Nat Rev Cardiol 8: 30-41.

20. Tongers J, Losordo DW, Landmesser U (2011) Stem and progenitor cell-based therapy in ischaemic heart disease: promise, uncertainties, and challenges. Eur Heart J 32: 1197-1206.
21. Donndorf P, Strauer BE, Steinhoff G (2012) Update on cardiac stem cell therapy in heart failure. Curr Opin Cardiol 27: 154-160.

22. Müller P, Beltrami AP, Cesselli D, Pfeiffer P, Kazakov A, et al. (2005) Myocardia regeneration by endogenous adult progenitor cells. J Mol Cell Cardiol 39: 377 387

23. Wagers AJ, Weissman IL (2004) Plasticity of adult stem cells. Cell 116: 639 648.

24. Beltrami AP, Cesselli D, Beltrami CA (2009) Pluripotency rush! Molecular cues for pluripotency, genetic reprogramming of adult stem cells, and widely multipotent adult cells. Pharmacol Ther 124: 23-30.

25. Anversa P, Leri A, Kajstura J, Nadal-Ginard B (2002) Myocyte growth and cardiac repair. J Mol Cell Cardiol 34: 91-105.

26. Urbanek K, Quaini F, Tasca G, Torella D, Castaldo C, et al. (2003) Intense myocyte formation from cardiac stem cells in human cardiac hypertrophy. Proc Natl Acad Sci USA 100: 10440-10445

27. Bergmann O, Bhardwaj RD, Bernard S, Zdunek S, Barnabé-Heider F, et al (2009) Evidence for cardiomyocyte renewal in humans. Science 324: 98-102.

28. Anversa P, Kajstura J (1998) Ventricular myocytes are not terminally differentiated in the adult mammalian heart. Circ Res 83: 1-14.

29. Bersell K, Arab S, Haring B, Kühn B (2009) Neuregulin1/ErbB4 signaling induces cardiomyocyte proliferation and repair of heart injury. Cell 138: 257 270

30. Quaini F, Urbanek K, Beltrami AP, Finato N, Beltrami CA, et al. (2002) Chimerism of the transplanted heart. N Engl J Med 346: 5-15.

31. Müller P, Pfeiffer $P$, Koglin J, Schäfers HJ, Seeland U, et al. (2002) Cardiomyocytes of noncardiac origin in myocardial biopsies of human transplanted hearts. Circulation 106: 31-35.

32. Bailey B, Izarra A, Alvarez R, Fischer KM, Cottage CT, et al. (2009) Cardiac stem cell genetic engineering using the alphaMHC promoter. Regen Med 4 823-833

33. Hierlihy AM, Seale P, Lobe CG, Rudnicki MA, Megeney LA (2002) The postnatal heart contains a myocardial stem cell population. FEBS Lett 530: 239 243.

34. Martin CM, Meeson AP, Robertson SM, Hawke TJ, Richardson JA, et al. (2004) Persistent expression of the ATP-binding cassette transporter, Abcg2, identifies cardiac SP cells in the developing and adult heart. Dev Biol 265: 262-275

35. Oh H, Bradfute SB, Gallardo TD, Nakamura T, Gaussin V, et al. (2003) Cardiac progenitor cells from adult myocardium: homing, differentiation, and fusion after infarction. Proc Natl Acad Sci USA 100: 12313-12318.

36. Lira A, Kajstura J, Anversa P (2005) Cardiac stem cells and mechanisms of myocardial regeneration. Physiol Rev 85: 1373-1416.

37. Beltrami AP, Cesselli D, Bergamin N, Marcon P, Rigo S, et al. (2007) Multipotent cells can be generated in vitro from several adult human organs (heart, liver and bone marrow). Blood 110: 3438-3446.

38. Martin-Puig S, Wang Z, Chien KR (2008) Lives of a heart cell: tracing the origins of cardiac progenitors. Cell Stem Cell 2: 320-331.

39. Kirkland MA (2004) A phase space model of hemopoiesis and the concept of stem cell renewal. Exp Hematol 32: 511-519.

40. Cai CL, Liang X, Shi Y, Chu PH, Pfaff SL, et al. (2003) Isl1 identifies a cardiac progenitor population that proliferates prior to differentiation and contributes a majority of cells to the heart. Dev Cell 5: 877-889.

41. Moretti A, Caron L, Nakano A, Lam JT, Bernshausen A, et al. (2006) Multipotent embryonic isl1+ progenitor cells lead to cardiac, smooth muscle and endothelial cell diversification. Cell 127: 1151-1165.

42. Kouskoff V, Lacaud G, Schwantz S, Fehling HJ, Keller G (2005) Sequentia development of hematopoietic and cardiac mesoderm during embryonic stem cell differentiation. Proc Natl Acad Sci USA 102: 13170-13175.

43. Zhou B, Ma Q, Rajagopal S, Wu SM, Domian I, et al. (2008) Epicardia progenitors contribute to the cardiomyocyte lineage in the developing heart. Nature 454: 109-113.

44. Cai CL, Martin JC, Sun Y, Cui L, Wang L, et al. (2008) A myocardial lineage derives from Tbx18 epicardial cells. Nature 454: 104-108. 
Citation: Beltrami AP, Cesselli D, Beltrami CA (2012) Cardiac Resident Stem Cells: Work (Still) in Progress. J Stem Cell Res Ther S9:001. doi:10.4172/2157-7633.S9-001

Page 10 of 12

45. Christoffels VM, Grieskamp T, Norden J, Mommersteeg MT, Rudat C, et al. (2009) Tbx18 and the fate of epicardial progenitors. Nature 458: E8-9; discussion E9-10.

46. Katz TC, Singh MK, Degenhardt K, Rivera-Feliciano J, Johnson RL, et al. (2012) Distinct compartments of the proepicardial organ give rise to coronary vascular endothelial cells. Dev Cell 22: 639-650.

47. Hosoda T, D'Amario D, Cabral-Da-Silva MC, Zheng H, Padin-Iruegas ME, et al. (2009) Clonality of mouse and human cardiomyogenesis in vivo. Proc Nat Acad Sci USA 106: 17169-17174

48. Goodell MA, Brose K, Paradis G, Conner AS, Mulligan RC (1996) Isolation and functional properties of murine hematopoietic stem cells that are replicating in vivo. J Exp Med 183: 1797-1806.

49. Abu-Issa R, Kirby ML (2007) Heart field: from mesoderm to heart tube. Annu Rev Cell Dev Biol 23: 45-68.

50. Kelly RG, Brown NA, Buckingham ME (2001) The arterial pole of the mouse heart forms from Fgf10-expressing cells in pharyngeal mesoderm. Dev Cell 1 : 435-440

51. Buckingham M, Meilhac S, Zaffran S (2005) Building the mammalian heart from two sources of myocardial cells. Nat Rev Genet 6: 826-835.

52. Garry DJ, Olson EN (2006) A common progenitor at the heart of development. Cell 127: 1101-1104.

53. Stoller JZ, Epstein JA (2005) Cardiac neural crest. Semin Cell Dev Biol 16 704-715.

54. Winter EM, Gittenberger-de Groot AC (2007) Epicardium-derived cells in cardiogenesis and cardiac regeneration. Cell Mol Life Sci 64: 692-703.

55. Wu SM, Fujiwara Y, Cibulsky SM, Clapham DE, Lien CL, et al. (2006) Developmental origin of a bipotential myocardial and smooth muscle cel precursor in the mammalian heart. Cell 127: 1137-1150.

56. Tallini YN, Greene KS, Craven M, Spealman A, Breitbach M, et al. (2009) c-kit expression identifies cardiovascular precursors in the neonatal heart. Proc Nat Acad Sci USA 106: 1808-1813.

57. Fransioli J, Bailey B, Gude NA, Cottage CT, Muraski JA, et al. (2008) Evolution of the c-kit-positive cell response to pathological challenge in the myocardium. Stem Cells 26: 1315-1324.

58. Ferreira-Martins J, Ogórek B, Cappetta D, Matsuda A, Signore S, et al. (2012) Cardiomyogenesis in the developing heart is regulated by c-kit-positive cardiac stem cells. Circ Res 110: 701-715.

59. de la Cruz MV, Sánchez Gómez C, Arteaga MM, Argüello C (1977) Experimental study of the development of the truncus and the conus in the chick embryo. $J$ Anat 123: 661-686.

60. Laugwitz KL, Moretti A, Lam J, Gruber P, Chen Y, et al. (2005) Postnatal isl1+ cardioblasts enter fully differentiated cardiomyocyte lineages. Nature 433: 647653.

61. Wada AM, Smith TK, Osler ME, Reese DE, Bader DM (2003) Epicardial/ Mesothelial cell line retains vasculogenic potential of embryonic epicardium. Circ Res 92: 525-531.

62. Mikawa T, Gourdie RG (1996) Pericardial mesoderm generates a population of coronary smooth muscle cells migrating into the heart along with ingrowth of the epicardial organ. Dev Biol 174: 221-232.

63. Lie-Venema H, van den Akker NM, Bax NA, Winter EM, Maas S, et al. (2007) Origin, fate, and function of epicardium-derived cells (EPDCs) in normal and abnormal cardiac development. ScientificWorldJournal 7: 1777-1798.

64. van Tuyn J, Atsma DE, Winter EM, van der Velde-van Dijke I, Pijnappels DA et al. (2007) Epicardial cells of human adults can undergo an epithelial-tomesenchymal transition and obtain characteristics of smooth muscle cells in vitro. Stem Cells 25: 271-278.

65. Di Meglio F, Castaldo C, Nurzynska D, Romano V, Miraglia R, et al. (2010) Epithelial-mesenchymal transition of epicardial mesothelium is a source of cardiac CD117-positive stem cells in adult human heart. J Mol Cell Cardio 49: $719-727$

66. Zhou B, Honor LB, He H, Ma Q, Oh JH, et al. (2011) Adult mouse epicardium modulates myocardial injury by secreting paracrine factors. J Clin Invest 121 : 1894-1904.
67. Smart N, Bollini S, Dubé KN, Vieira JM, Zhou B, et al. (2011) De novo cardiomyocytes from within the activated adult heart after injury. Nature 474 640-644.

68. Prindull G, Zipori D (2004) Environmental guidance of normal and tumor cell plasticity: epithelial mesenchymal transitions as a paradigm. Blood 103: 28922899

69. Thiery JP, Acloque H, Huang RY, Nieto MA (2009) Epithelial-mesenchyma transitions in development and disease. Cell 139: 871-890.

70. Männer J, Pérez-Pomares JM, Macías D, Muñoz-Chápuli R (2001) The origin, formation and developmental significance of the epicardium: a review. Cells Tissues Organs 169: 89-103.

71. Poss KD, Wilson LG, Keating MT (2002) Heart regeneration in zebrafish Science 298: 2188-2190.

72. Lepilina A, Coon AN, Kikuchi K, Holdway JE, Roberts RW, et al. (2006) A dynamic epicardial injury response supports progenitor cell activity during zebrafish heart regeneration. Cell 127: 607-619.

73. Wills AA, Holyday JE, Major RJ, Poss KD (2008) Regulated addition of new myocardial and epicardial cells fosters homeostatic cardiac growth and maintenance in adult zebrafish. Development 135: 183-192.

74. Limana F, Bertolami C, Mangoni A, Di Carlo A, Avitabile D, et al. (2010) Myocardial infarction induces embryonic reprogramming of epicardial c-kit(+) cells: Role of the pericardial fluid. J Mol Cell Cardiol 48: 609-618.

75. Smart N, Risebro CA, Melville AA, Moses K, Schwartz RJ, et al. (2007) Thymosin beta4 induces adult epicardial progenitor mobilization and neovascularization. Nature 445: 177-182.

76. Zhou B, Pu WT (2011) Epicardial epithelial-to-mesenchymal transition in injured heart. J Cell Mol Med 15: 2781-2783.

77. Castaldo C, Di Meglio F, Nurzynska D, Romano G, Maiello C, et al. (2008) CD117-positive cells in adult human heart are localized in the subepicardium and their activation is associated with laminin-1 and alpha6 integrin expression. Stem Cells 26: 1723-1731.

78. Iwano M, Plieth D, Danoff TM, Xue C, Okada H, et al. (2002) Evidence that fibroblasts derive from epithelium during tissue fibrosis. J Clin Invest 110: 341 350 .

79. Zeisberg EM, Tarnavski O, Zeisberg M, Dorfman AL, McMullen JR, et al. (2007) Endothelial-to-mesenchymal transition contributes to cardiac fibrosis. Nat Med 13: $952-961$

80. Murtuza B, Nichol JW, Khademhosseini A (2009) Micro- and nanoscale contro of the cardiac stem cell niche for tissue fabrication. Tissue Eng Part B Rev 15 $443-454$

81. Li L, Xie T (2005) Stem cell niche: structure and function. Annu Rev Cell Dev Biol 21: 605-631.

82. Kizana E, Cingolani E, Marban E (2009) Non-cell-autonomous effects of vector-expressed regulatory RNAs in mammalian heart cells. Gene Ther 16 1163-1168.

83. Boni A, Urbanek K, Nascimbene A, Hosoda T, Zheng H, et al. (2008) Notch1 regulates the fate of cardiac progenitor cells. Proc Natl Acad Sci USA 105 15529-15534.

84. Ferreira-Martins J, Rondon-Clavo C, Tugal D, Korn JA, Rizzi R, et al. (2009) Spontaneous calcium oscillations regulate human cardiac progenitor cell growth. Circ Res 105: 764-774.

85. Ghafar-Zadeh E, Waldeisen JR, Lee LP (2011) Engineered approaches to the stem cell microenvironment for cardiac tissue regeneration. Lab Chip 11: 3031 3048

86. Murasawa S, Kawamoto A, Horii M, Nakamori S, Asahara T (2005) Nichedependent translineage commitment of endothelial progenitor cells, not cell fusion in general, into myocardial lineage cells. Arterioscler Thromb Vasc Bio 25: $1388-1394$

87. Orlic D, Kajstura J, Chimenti S, Jakoniuk I, Anderson SM, et al. (2001) Bone marrow cells regenerate infarcted myocardium. Nature 410: 701-705.

88. Rota M, Kajstura J, Hosoda T, Bearzi C, Vitale S, et al. (2007) Bone marrow cells adopt the cardiomyogenic fate in vivo. Proc Natl Acad Sci USA 104: 17783-17788. 
89. Cesselli D, Beltrami AP, Rigo S, Bergamin N, D'Aurizio F, et al. (2009) Multipotent progenitor cells are present in human peripheral blood. Circ Res 104: $1225-1234$

90. Tang XL, Rokosh G, Sanganalmath SK, Yuan F, Sato H, et al. (2010) Intracoronary administration of cardiac progenitor cells alleviates left ventricular dysfunction in rats with a 30-day-old infarction. Circulation 121: 293-305.

91. Takehara N, Tsutsumi $\mathrm{Y}$, Tateishi K, Ogata T, Tanaka H, et al. (2008) Controlled delivery of basic fibroblast growth factor promotes human cardiosphere-derived cell engraftment to enhance cardiac repair for chronic myocardial infarction. $J$ Am Coll Cardiol 52: 1858-1865.

92. Menasché $\mathrm{P}$, Alfieri $\mathrm{O}$, Janssens $\mathrm{S}$, McKenna W, Reichenspurner $\mathrm{H}$, et al. (2008) The Myoblast Autologous Grafting in Ischemic Cardiomyopathy (MAGIC) trial: first randomized placebo-controlled study of myoblast transplantation. Circulation 117: 1189-1200.

93. Murry CE, Soonpaa MH, Reinecke H, Nakajima H, Nakajima HO, et al. (2004) Haematopoietic stem cells do not transdifferentiate into cardiac myocytes in myocardial infarcts. Nature 428: 664-668.

94. Balsam LB, Wagers AJ, Christensen JL, Kofidis T, Weissman IL, et al. (2004) Haematopoietic stem cells adopt mature haematopoietic fates in ischaemic myocardium. Nature 428: 668-673.

95. Kajstura J, Rota M, Whang B, Cascapera S, Hosoda T, et al. (2005) Bone marrow cells differentiate in cardiac cell lineages after infarction independently of cell fusion. Circ Res 96: 127-137.

96. Mirotsou M, Jayawardena TM, Schmeckpeper J, Gnecchi M, Dzau VJ, et al. (2011) Paracrine mechanisms of stem cell reparative and regenerative actions in the heart. J Mol Cell Cardiol 50: 280-289.

97. Sahoo S, Klychko E, Thorne T, Misener S, Schultz KM, et al. (2011) Exosomes From Human CD34+ Stem Cells Mediate Their Proangiogenic Paracrine Activity. Circ Res 109: 724-728.

98. Takahashi K, Yamanaka S (2006) Induction of Pluripotent Stem Cells from Mouse Embryonic and Adult Fibroblast Cultures by Defined Factors. Cell 126 663-676.

99. Carpenter L, Carr C, Yang CT, Stuckey DJ, Clarke K, et al. (2012) Efficient differentiation of human induced pluripotent stem cells generates cardiac cells that provide protection following myocardial infarction in the rat. Stem Cells Dev 21: 977-986.

100. Yoshida Y, Yamanaka S (2011) iPS cells: a source of cardiac regeneration. J Mol Cell Cardiol 50: 327-332.

101. Martinez-Fernandez A, Nelson TJ, Terzic A (2011) Nuclear reprogramming strategy modulates differentiation potential of induced pluripotent stem cells. $J$ Cardiovasc Transl Res 4: 131-137.

102. Rizzi R, Di Pasquale E, Portararo P, Papait R, Cattaneo P, et al. (2012) Post-natal cardiomyocytes can generate iPS cells with an enhanced capacity toward cardiomyogenic re-differentation. Cell Death Differ 19: 1162-1174.

103. Efe JA, Hilcove S, Kim J, Zhou H, Ouyang K, et al. (2011) Conversion of mouse fibroblasts into cardiomyocytes using a direct reprogramming strategy. Nat Cell Biol 13: 215-222.

104. Jayawardena TM, Egemnazarov B, Finch EA, Zhang L, Payne JA, et al. (2012) MicroRNA-Mediated In Vitro and In Vivo Direct Reprogramming of Cardiac Fibroblasts to Cardiomyocytes. Circ Res 110: 1465-1473.

105. Schächinger V, Erbs S, Elsässer A, Haberbosch W, Hambrecht R, et al. (2006) Improved clinical outcome after intracoronary administration of bone-marrowderived progenitor cells in acute myocardial infarction: final 1-year results of the REPAIR-AMI trial. Eur Heart J 27: 2775-2783.

106. Li TS, Cheng K, Malliaras K, Smith RR, Zhang Y, et al. (2012) Direct comparison of different stem cell types and subpopulations reveals superior paracrine potency and myocardial repair efficacy with cardiosphere-derived cells. J Am Coll Cardiol 59: 942-953.

107. Cesselli D, Beltrami AP, D'Aurizio F, Marcon P, Puppato E, et al. (2009) Age and Pathology Impair Cardiac Stem Cells. Circulation 120: S595-S595.

108. D'Amario D, Cabral-Da-Silva MC, Zheng H, Fiorini C, Goichberg P, et al. (2011) Insulin-like growth factor-1 receptor identifies a pool of human cardiac stem cells with superior therapeutic potential for myocardial regeneration. Circ Res 108: 1467-1481.
109.D'Amario D, Fiorini C, Campbell PM, Goichberg P, Sanada F, et al. (2011) Functionally competent cardiac stem cells can be isolated from endomyocardial biopsies of patients with advanced cardiomyopathies. Circ Res 108: 857-861.

110. Beltrami AP, Cesselli D, Beltrami CA (2012) Stem cell senescence and regenerative paradigms. Clin Pharmacol Ther 91: 21-29.

111. Cesselli D, Caragnano A, Bergamin N, et al. (2012) Pharmacologic Inhibition of Cardiac Stem Cell Senescence. In Nagata T (Ed.), Senescence. Japan: INTECH.

112. Beltrami AP, Cesselli D, Beltrami CA (2011) At the stem of youth and health Pharmacol Ther 129: 3-20

113. Katare R, Caporali A, Zentilin L, Avolio E, Sala-Newby G, et al. (2011) Intravenous gene therapy with PIM-1 via a cardiotropic viral vector halts the progression of diabetic cardiomyopathy through promotion of prosurvival signaling. Circ Res 108: 1238-1251.

114. Povsic TJ, O'Connor CM, Henry T, Taussig A, Kereiakes DJ, et al. (2011) A double-blind, randomized, controlled, multicenter study to assess the safety and cardiovascular effects of skeletal myoblast implantation by cathete delivery in patients with chronic heart failure after myocardial infarction. Am Heart J 162: 654-662.e1.

115. Bartunek J, Wijns W, Dolatabadi D, Vanderheyden M, Dens J, et al. (2011) C-Cure Multicenter Trial: Lineage Specified Bone Marrow Derived Cardiopoietic Mesenchymal Stem Cells for Treatment of Ischemic Cardiomyopathy. Journal of the American College of Cardiology 57: E200-E200

116. Hare JM, Traverse JH, Henry TD, Dib N, Strumpf RK, et al (2009) A randomized double-blind, placebo-controlled, dose-escalation study of intravenous adult human mesenchymal stem cells (prochymal) after acute myocardial infarction. J Am Coll Cardiol 54: 2277-2286.

117. Kang HJ, Kim HS, Zhang SY, Park KW, Cho HJ, et al. (2004) Effects of intracoronary infusion of peripheral blood stem-cells mobilised with granulocyte-colony stimulating factor on left ventricular systolic function and restenosis after coronary stenting in myocardial infarction: the MAGIC cell randomised clinical trial. Lancet 363: 751-756.

118. Assmus B, Honold J, Schächinger V, Britten MB, Fischer-Rasokat U, et al (2006) Transcoronary transplantation of progenitor cells after myocardial infarction. N Engl J Med 355: 1222-1232.

119. Losordo DW, Henry TD, Davidson C, Sup Lee J, Costa MA, et al. (2011) Intramyocardial, autologous CD34+ cell therapy for refractory angina. Circ Res 109: 428-436.

120. Tendera M, Wojakowski W, Ruzyło W, Chojnowska L, Kepka C, et al. (2009) intracoronary infusion of bone marrow-derived selected CD34+CXCR4+ cells and non-selected mononuclear cells in patients with acute STEMI and reduced left ventricular ejection fraction: results of randomized, multicentre Myocardial Regeneration by Intracoronary Infusion of Selected Population of Stem Cells in Acute Myocardial Infarction (REGENT) Trial. Eur Heart J 30: 1313-1321.

121. Nasseri BA, Kukucka M, Dandel M (2012) Autologous Cd133+ Bone Marrow Cells and Bypass Grafting for Regeneration of Ischemic Myocardium: Results of the Cardio133 Trial. Journal of the American College of Cardiology 59: E864-E864

122. Adler DS, Lazarus H, Nair R, Goldberg JL, Greco NJ, et al. (2011) Safety and efficacy of bone marrow-derived autologous CD133+ stem cell therapy. Front Biosci (Elite Ed) 3: 506-514

123. Bartunek J, Vanderheyden M, Vandekerckhove B, Mansour S, De Bruyne B et al. (2005) Intracoronary injection of CD133-positive enriched bone marrow progenitor cells promotes cardiac recovery after recent myocardial infarction: feasibility and safety. Circulation 112: |178-I183.

124. Schächinger V, Erbs S, Elsässer A, Haberbosch W, Hambrecht R, et al. (2006) Intracoronary bone marrow-derived progenitor cells in acute myocardial infarction. N Engl J Med 355: 1210-1221.

125. Roncalli J, Mouquet F, Piot C, Trochu JN, Le Corvoisier P, et al. (2011) Intracoronary autologous mononucleated bone marrow cell infusion for acute myocardial infarction: results of the randomized multicenter BONAMI trial. Eu Heart J 32: 1748-1757.

126. van Ramshorst J, Bax JJ, Beeres SL, Dibbets-Schneider P, Roes SD, et al. (2009) Intramyocardial bone marrow cell injection for chronic myocardial schemia: a randomized controlled trial. JAMA 301: 1997-2004. 
Citation: Beltrami AP, Cesselli D, Beltrami CA (2012) Cardiac Resident Stem Cells: Work (Still) in Progress. J Stem Cell Res Ther S9:001. doi:10.4172/2157-7633.S9-001

127. Charwat S, Lang I, Dettke M, Graf S, Nyolczas N, et al. (2010) Effect of intramyocardial delivery of autologous bone marrow mononuclear stem cells on the regional myocardial perfusion. NOGA-guided subanalysis of the MYSTAR prospective randomised study. Thromb Haemost 103: 564-571.

128. Janssens S, Dubois C, Bogaert J, Theunissen K, Deroose C, et al. (2006) Autologous bone marrow-derived stem-cell transfer in patients with STsegment elevation myocardial infarction: double-blind, randomised controlled trial. Lancet 367: 113-121.

129. Hirsch A, Nijveldt R, van der Vleuten PA, Tijssen JG, van der Giessen WJ, et al. (2011) Intracoronary infusion of mononuclear cells from bone marrow or peripheral blood compared with standard therapy in patients after acute myocardial infarction treated by primary percutaneous coronary intervention: results of the randomized controlled HEBE trial. Eur Heart J 32: 1736-1747.

130. Huikuri HV, Kervinen K, Niemelä M, Ylitalo K, Säily M, et al. (2008) Effects of intracoronary injection of mononuclear bone marrow cells on left ventricular function, arrhythmia risk profile, and restenosis after thrombolytic therapy of acute myocardial infarction. Eur Heart J 29: 2723-2732.

131. Cao F, Sun D, Li C, Narsinh K, Zhao L, et al. (2009) Long-term myocardial functional improvement after autologous bone marrow mononuclear cells transplantation in patients with ST-segment elevation myocardial infarction: 4 years follow-up. Eur Heart J 30: 1986-1994.

132. Wollert KC, Meyer GP, Lotz J, Ringes-Lichtenberg S, Lippolt P, et al. (2004) Intracoronary autologous bone-marrow cell transfer after myocardial infarction: the BOOST randomised controlled clinical trial. Lancet 364: 141-148.

133. Lunde K, Solheim S, Aakhus S, Arnesen H, Abdelnoor M, et al. (2006) Intracoronary injection of mononuclear bone marrow cells in acute myocardial infarction. N Engl J Med 355: 1199-1209.
This article was originally published in a special issue, Cardiac Resident

Stem Cells \& Progenitors handled by Editor(s). Dr. Vincenzo Lionetti, Scuola Superiore Sant Anna University, Italy 